the geologist will have disappeared. At the mammoth hot springs the activity is not one-tenth that of former times, Minerva Terrace having become extinct (since 1895); the discharge from Pulpit and J upiter Terraces having greatly declined during the same period and the Narrow Gauge-a fissure vent-and other attractions, having become all but extinct. Roaring Mountain is now silent though steaming. In the Norris Geyser Basin the Black Growler is less active. In the Lower Basin the splendid Fountain Geyser is extinct, with a feeble substitute near by, called the Dewey. The Giant Paint Pots are greatly contracted in size-the pink half being extinct. In the Upper Basin some of the better known as well as many of the lesser geysers are extinct or supposed to be. Among these are the Splendid Geyser and the Beehive Geyser. The Grand Geyser, which used to erupt daily, now erupts irregularly about three times a season. The Cascade, which erupted about every quarter of an hour in 1895 now erupts once a day.

The general impression of frequenters of the Park is that the changes are serious and much more rapid than is generally believed.

'Greatest Area and Thickness of the North American Ice Sheet,' Warren Upham, St. Paul, Minn.

From the overlapping and intermingling of the drift deposits the indications are that the ice sheet at its culmination reached continuously across the continent from New England to British Columbia or southeastern Alaska, interrupted only in its southern part by the projecting ranges of the Rocky Mountains. The conclusions of Dr. G. M. Dawson that the Cordilleran glaciation mainly preceded the glaciation of the Laur-' entine region and of the great plains stretching westward nearly to the Rocky Mountains, and that the maximum extension of the Laurentide ice sheet was attended by a depression of the Cordilleran region, with a subsequent elevation of about 5,300 feet, is not apparently borne out by the facts. The probabilities seem to be that the Cordilleran and Laurentide ice sheets, having been each accumulated because of high continental altitude much exceeding that of the present time, were confluent along the east side of the Rocky Mountains, a continuous ice sheet at the north extending from the east to the west side of the continent.

In Minnesota and North Dakota observations on each side of the Glacial Lake Agassiz oppose the view of Tyrrell that the Laurentide ice sheet was preceded by a Keewatin ice sheet. Facts in connection with glacial lake deltas and overlapping drift deposits demonstrate contemporaneous glaciation meeting from the northwest and northeast. There is also evidence that the northwestern ice field, belonging to the Keewatin of Tyrrell, pushed back the northeastern ice field, referable to the Laurentide, showing that there the greatest extension of the Keewatin was later. From the northwest and northeast, however, the two ice fields were confluent. This great ice sheet northward, as evidenced by the height of mountain glaciation, attained a maximum thickness of one to two miles nearly across the continent, the thickness being greatest upon the Laurentide highlands.

\section{Arthur Hollick,}

Columbia University. Secretary.

\section{SCIENTIFIC BOOKS.}

Catalogus Mammalium tam viventium quam fossilium. By Dr. E. L. Trouessart. Berlin, R. Friedländer \& Sohn. New ed., fasciculus VI., Appendix and Index, $1899,8^{\circ}$ pp. 12651469. Price of complete work 66 Marks. The completion of the great 'Catalogus Mammalium' which Dr. Trouessart has been publishing in parts during the past two years marks an epoch in systematic work in mammals. Previous catalogues, incomplete at best, have been restricted either to living or extinct forms, so that zoologists have been obliged to 
consult one set and paleontologists another. But as Professor Osborn has recently remarked: "Among the vertebrates the separation of the living and extinct forms is at present a calamity. Zoologists must become familiar with paleontology whether they prefer to do so or not. It is impossible, for example, to understand the modern races of dogs without studying the Oligocene races and their ancestors." * Dr. Trouessart has sought to remedy this defect by bringing together in one list all the species of mammals, living and extinct, which have been described between 1758 (the date of publication of the 10th edition of the 'Systema Naturæ' of Linnaeus) and the close of the year 1898-a period covering exactly a century and a half.

The first three parts of this catalogue have already been reviewed in these pages $; \dagger$ without attempting to treat the others with the same detail, attention may be called to a few points which are suggested more especially by the last brochure. The catalogue proper consists of 5 parts containing 1,264 pages, while fasciculus VI. is devoted entirely to addenda and corrigenda (94 pp.) and a closely printed 3 column index of 109 pages.

The index has some 16,827 entries indicating that over 16,000 names have been listed; of these 2,977 are generic and 13,850 specific. The total number of recognized genera and sub. genera is 1,840 ; of recognized species about 7,500. These numbers are significant as an index of progress in the study of mammals. In 1758, 39 genera and 183 species were described by Linnaeus; in 1798 the -total number of recognized genera was less than 100 of which only 1 was extinct; while in 1898 the number of genera and subgenera recognized by Trouessart is 1,840. This rapid increase in names within the present century has resulted from the more thorough exploration of all parts of the globe, more careful study of improved material, and especially from the marvelous development in our knowledge of extinct forms.

Naturally the naming of so many species has presented many difficulties and even a superficial examination of the catalogue shows many

*Science, N. S., X., p. 171, August 11, 1899.

†SCIENCE, N. S., VI., pp. 68-69, July 9, 1897 ; VII., pp. 30-33, January 7, 1898. curiosities of nomenclature. The names vary in length from one to ten syllables, the shortest being Mus rex and the longest Brachydiastematotherium transsylvanicum. The tendency to repeat favorite specific names in many groups is very noticeable; major has been applied to 51 species, intermedius to 54 , robustus to 56 , gracilis to 65 , and minor to 71 . Many species have been named in honor of eminent naturalists ; the zoologists who have had a dozen or more mammals named after them are : Blanford, 12 ; Allen, Gray and Lartet each, 13 ; Gervais and Owen, 15; Geoffroy, 17 ; Gaudry, 20 ; Milne Edwards, 21 ; and Cuvier, 28.

That such a catalogue necessarily contains some errors is self-evident, but the wonder is that there are not more of them. There are of course omissions (e.g., a genus, subgenus and 5 species of phyllostome bats described by Miller in the Proceedings of the Philadelphia Academy Science, in July, 1898); errors in the authority of genera and species and in the authors of papers (e.g., in crediting Bailey's 'List of Mammals of the District of Columbia' to Bangs); adoption of the wrong names for groups, thus differentiating forms which are identical while reducing others to synonomy which are really distinct. But the care which the author has taken to eliminate errors of all kinds is shown by the voluminous appendix of 94 pages devoted to corrections and additions of genera and species which were omitted, or which have been described during the two years in which the catalogue has been passing through the press.

The most serious defect in the catalogue seems to be in the treatment of genera. References are so seldom given that it is difficult to consult the original descriptions. Moreover the 2,977 generic names indexed probably do not represent much more than 65 per cent. of those actually published, so that in some cases names which have the best claim to adoption are not even mentioned. It should be stated that the author's aim has been to adopt the best known or most generally used name for a genus, on the plea that the work would thus be more generally useful-in short he has in many cases followed the auctorum plurimorum rule rather than the law of priority. He has thus been led to 
adopt some names which are preoccupied, but in this respect there is a marked improvement in the latter part of the catalogue. The selection of the best known designation, regardless of whether the name is preoccupied or antedated, is likely to lead to more trouble than convenience in the long run. Changes in names are always objectionable, particularly in higher groups, but it is safe to say that nearly 5 per cent. of all the genera and subgenera in this catalogue are likely to undergo change within a few years. Dr. Trouessart might have prevented much trouble for students in future by making the changes now demanded by the law of priority. Even if he preferred to adopt the other course in the body of the list, a table might have been inserted in the appendix showing the earliest names of groups for which he had selected the best known designation, but even this seems to have been impracticable on account of the undue length of the appendix.

Without attempting to give such a table here, it will suffice to illustrate this point by mentioning 50 genera and subgenera which have not been corrected in the appendix. It should be explained, however, that these do not by any means include all the names which rest on an unstable basis. Full references are added, as some of the genera are not given in the catalogue, although the majority of them are mentioned in synonymy with merely authorities and dates.

Page 4. For Siamanga, 1843-substitute Symphalangus Gloger, Hand- u. Hilfsb. Naturgesch., I., p. 34, 1841.

P. 44. For Brachyurus, * 1823-Cacajao Lesson, Species des Mamm., pp. 181-183, 1840.

* Trouessart's Brachyurus contains two subgenera : A, Ouakaria Gray, 1849 and B, Brachyurus. Since Brachyurus Spix, 1823, is preoccupied by Brachyurus Fischer, 1813, a group of field mice, the genus becomes Cacajao Lesson, 1840, and subgenus A, Ouakaria also becomes Cacajao both being based on Simia melanocephala. Subgenus B, Brachyurus including the redfaced species, if really worthy of separation, apparently requires a new name and may be called Cothurus (docked tail). Ouakaria is not available for this group as it has already been restricted to the blackheaded forms and Cercoptochus Gloger, 1841, based on the uakaris in general, must be restricted to the same group since it was proposed before any of the redfaced species had been described.
P. 44. For subgenus Brachyurus TrouessartCothurus nom. nov. Type Brachyurus calvus Geoff.

P. 46. For Chrysothrix, 1835-Saimiri Voigt, Cuvier's Thierreich, I., p. 95, 1831.

P. 47. For Nyctipithecus, 1823-Aotus Humbolt, Recueil Obs. Zool. Anat. Comp., I., pp. 306-311, 358, 1811.

P. 62. For Cheiromys, 1799-Daubentonia Geoffroy, Décad. Philos., IV., p. 193, 1795.

P. 66. For Hemigalago, 1857-Galagoides Smith, S. Afr. Quart. Journ., 2d ser., II., p. 32, 1833.

P. 84. For Cynonycteris, 1852-Rousettus Gray, London Med. Repos., XV., p. 299, 1821. P. 90. For Megaloglossus,* 1885-Trygenycteris Lydekker, in Flower \& Lydekker's, Mamm. Living \& Extinct, p. 655, 1891.

P. 135. For Furia, * 1828-Furipterus Bonaparte, Icon. Fauna Italica, I., fasc. XXI. (under Plecotus auritus), 1837.

P. 149. For Mystacina,* 1843-Mystacops Lydekker, in Flower \& Lydekker's, Mamm., Living \& Extinct, p. 671, 1891.

P. 152. For Macrotus, * 1843-Otopterus Lydekker, in Flower \& Lydekker's, Mamm., Living \& Extinct, p. 673, 1891.

P. 153. For Lophostoma, 1838-Tonatia Gray, Griffith's Cuvier, Anim. Kingdom, V., p. 71, footnote, 1827.

P. 155. Tylostoma, * 1855-Anthorhina Lydekker, in Flower \& Lydekker's, Mamm., Living \& Extinct, p. 674, 1891.

P. 156. For Carollia, ${ }^{*} 1838$-Hemiderma Gervais, Expéd. Comte de Castelnau l'Am. du Sud, Mamm., p. 43, 1855.

P. 158. For Ischnoglossa, * 1860-Leptonycteris Lydekker, in Flower \& Lydekker's, Mamm. Living \& Extinct, p. 674, 1891.

P. 203. For Mygale, 1800-Desmana Güldenstädt, Beschäft. Berliner Gesellsch. Naturf. Freunde, III., p. 108, 1777.

P. 212. For Centetes, 1811-Tenrec Lacépède, Buffon's Hist. Nat., Didot ed., Quad., XIV., p. $156,1799$.

P. 248. For Cercoleptes, 1811-Potos Cuvier \& Geoff., Mag. Encyclopédique, II., p. 187, 1795.

P. 287. For Enhydra,* 1822-Latax Gloger,

* Preoccupied. 
Nova Acta Acad. Cæs. Leop.-Carol., XIII., pt. 2, p. 511, 1827.

P. 297. For Hypotemnodon, 1894-Mesocyon Scott, Princeton College Bull., II., p. 38, 1890.

P. 341. For Hemigalidia, 1882 - Salanoia, Gray, Proc. Zool. Soc. London, pp. 523-524, 1864.

P. 372. For Callorhinus, * 1859-Callotaria Palmer, Proc. Biol. Soc. Wash., VII., p. 156, 1892.

P. 375. For Trichechus, ${ }^{*}: 1766$-Odobenus

Brisson, Regnum Anim., 2d ed., pp. 12, 30-31, 1762.

P. 377. For Macrorhinus, * 1826-Mirounga Gray, Griffith's Cuvier, Anim. Kingdom, V., pp. 179-181, 1827.

P. 380. For Ogmorhinus, 1875-Hydrurga

Gistel, Naturgesch. Thierreichs, p. XI., 1848.

P. 421. For Macroxus, 1823-Guerlinguetus

Gray, London Med. Repos., XV., p. 304, 1821.

P. 453. For Myoxus, 1780-Glis Brisson,

Regn. Anim., 2d ed., pp. 13, 113-118, 1762.

P. 724. For Euprotogonia, Apr. 1893-Tetraclænodon Scott, Proc. Acad. Nat. Sci., Phila., Nov. 1892, pp. 299-300.

P. 754. For Ceratorhinus, 1867-Didermocerus $\dagger$ Brookes, Cat. Anat. and Zool. Museum, p. $75,1828$.

P. 817. For Dicotyles, 1817 - Tayassu G. Fischer, Zoognosia, III., pp. 284-289, 1814.

P. 835. For Oreodon,* 1851-Merycoidodon

Leidy, Proc. Acad. Nat. Sci., Phila., pp. 47-50, 1848.

P. 896. For Furcifer, ${ }^{*}$ 1844-Hippocamelus Leuckart, De Equo bisulco Molinæ, p. 24, 1816.

P. 950. For Hippotragus, 1846 -Ozanna Reichenbach, Vollst. Naturgesch. In- u. Auslandes, Säugeth., III., pp. 126-131, 1845.

P. 967. For Aploceros, 1827-Oreamnos Rafinesque, Am. Monthly Mag., II., p. 44, 1817.

P. 1000. For Manatus, 1772-Trichechus Lin. næus, Syst. Nat., ed. 10, I., p. 34, 1758.

P. 1003. For Eotherium,* 1875-Fotheroides nom. nov. Eotherium Owen is preoccupied by Eotherium Leidy, 1853, a genus of Perissodactyla.

* Preoccupied.

$\dagger$ If this name is considered invalid because published in a sale catalogue, the subgenus stands $D i$ cerorhinus Gloger, 1841.
P. 1007. For Halicore, 1811-Dugong Lacépède, in Buffon's Hist. Nat., Didot ed., Quad., XIV., p. 193, 1799.

P. 1008. For Rhytina, 1811-Hydrodamalis Retzius, Kongl. Vet. Acad. nya Handl., Stockholm, XV., p. 292, 1794.

P. 1009. For Zeuglodon, 1839-Basilosaurus Harlan, Trans. Am. Philos. Soc., new ser., IV., pp. 397-403, 1834.

P. 1016. For Argyrodelphis, Apr., 1894-Diochotichus Ameghino, Énum. Syn. Mamm. Foss. Eocène Patagonie, p. 182, Fev. 1894.

P. 1017. For Pontistes, 1885-Palaeopontoporia Doering, Exped. Rio Negro (Patagonia), III., Geol., pp. 437, 455, 1882.

P. 1037. For Tursio,* 1830-Lissodelphis Gloger, Hand- u. Hilfsbuch Naturgesch., I., p. $169,1841$.

P. 1042. For Neomeris, ${ }^{*}$ 1846-Neophocæna Palmer, Proc. Biol. Soc. Wash., XIII., p. 23, Jan., 1899.

P. 1048. For Orca,* 1846 - Orcinus Fitzinger, Wiss.- pop. Naturgesch. Säugeth, VI., pp. 204-217, 1860.

P. 1120. For Tamandua, $\dagger$ 1842-Uroleptes Wagler, Nat. Syst. d. Amphibien, p. 36, 1830.

P. 1121. For Cyclothurus, $\dagger$ 1842-Cyclopes Gray, London Med. Repos., XV., p. 305, 1821.

P. 1146. For Lysiurus, 1891 -Cabassous McMurtrie, Cuvier's Anim. Kingdom, I., p. 164, 1831.

P. 1261. For Echidna,* 1798-Tachyglossus Illiger, Prod. Syst. Mamm. Avium, p. 114, 1811.

P. 1263. For Proehidna, Nov., 1877 - Zaglossus Gill, Ann. Record Sci. \& Industry for 1876, p. CLXXI., May, 1877.

This list of exceptions to the generic names which Dr. Trouessart has adopted should not be considered as a reflection on the value of his work. Its main object is to illustrate the author's method of selecting names and to call attention to some of the earliest ones which do not happen to be now in common use. It has been prepared to increase, if possible, the usefulness of the work rather than to detract from it.

So far as species are concerned the catalogue is evidently much more complete, although, as

* Preoccupied.

† Usually quoted as 1825 , but in reality a nomen nudum previous to 1842 . 
pointed out above, there are a few omissions. There is, of course, room for diversity of opinion concerning the validity of some of the species which are given recognition, but no one can be personally familiar with the characters, history and synonomy of such a multitude of forms, and all that the author could do was to take the latest revision of each group as his guide. In adopting this course he has done all that could be expected and has produced a valuable résumé of the labors of specialists in many groups.

In fact, too much can hardly be said in favor of the catalogue. It represents an enormous amount of painstaking labor and will long remain a monument to the industry, patience and bibliographical skill of its author. It is indispensable to the student of mammals and its chief drawback is, perhaps, its high price (66 Marks), which may put the book beyond the reach of some who need it most.

Washington, D. C.

\section{T. S. Palmer.}

The Genera and Species of Blastoidea, with a list of the Specimens in the British Museum of Natural History. By F. A. BAtHeR. London. 1899. 8vo. Pp. $x+70$.

This list "attempts to provide a complete index to every name that has ever been applied to a real or supposed Blastoid genus or species." It also gives the names now considered valid, and the synonyms with 'cross-references from the latter to the former.' It cites the literature, " the bibliographic details being placed under" the name now valid. It catalogues all the specimens of Blastoidea contained in the Geological Department of the British Museum," and designates the specimens of historical interest, the types and figured specimens.

Bather's catalogue, like all of his work, is very detailed. The bibliographic references are not always mere title citations, but often give the important conclusions of writers, particularly those of synonymy. The list, however, 'is in no sense a revision' of the Blastoidea.

The important change in this list is the retention of Nucleocrinus, Conrad, 1842, in place of Elæacrinus, Roemer, 1851. Orbitremites, a nomen nudum of Gray, 1840, was established by T. \& T. Austin, 1842, and, therefore, displaces Granatocrinites, Troost, 1849 (nom. nud.), Granatocrinus, Hall, 1862, and Etheridge and Carpenter, 1886. Orophocrinus, von Seebach, 1864 , although in general use, should be displaced by Dimorphicrinus, d'Orbigny, 1849. Bather does not make this change, although he disapproves of Etheridge's and Carpenter's reason for rejecting this name, namely, Dineorphicrinus, "has never been adopted by paleontologists on account of the erroneous and incomplete nature of his generic diagnosis." On the same ground other names now in use can be rejected. The reviewer prefers to accept Dimorphicrinus.

The total number of specimens of Blastoidea in the British Museum is 1,223 , representing 73 species out of a total of about 166 listed species. "These figures speak for themselves. However numerous may be the specimens of Blastoidea in other museums, there can scarcely be any collection so representative of the class as a whole, or so rich in specimens of the highest scientific importance, as in that of the British Museum."

\section{U. S. National Museum.}

\section{Charles Schuchert.}

Grundlinien der Maritimen Meteorologie. Von Professor Dr. W. KöPPEN, AbtheilungsVorsteher an der Deutschen Seewarte. Hamburg, Verlag von G. W. Neumayer Nachfolger. 1899. 8vo. Pp. vi +83 .

There has for some time been need of just such a book as Dr. Köppen has now given us. We have a brief and elementary presentation of the fundamental principles of marine meteorology, arranged by a master of the subject, in attractive form. While the book is intended especially for seamen, and as an introduction to the more advanced Segelhandbücher of the German Naval Observatory at Hamburg, students of meteorology in general will find it admirably suited to their own use. There are six chapters, the subjects of which are as follows: I., instruments; II., the correlation of the weather elements ; III., the periodic variations of temperature, pressure, etc. ; IV., the geographic distribution of weather phenomena, 